\title{
Analysis on the Influence Mechanism of Social Capital Investment of New Energy Vehicle in Internet of Vehicles
}

\author{
Xiang Pan*, Xingzhi Lin
}

\author{
Guangxi Vocational Normal University, Nanning, China \\ *Corresponding author
}

\begin{abstract}
In recent years, new energy vehicles are booming in China-ASEAN, but the IOT of transportation based on new energy vehicles is still in its infancy. This paper analyzed the new formats of big data, location service and sharing economy of the IOT of new energy vehicle transportation in China-ASEAN, and established the construction model of the IOT of new energy vehicle transportation in China-ASEAN based on social capital. It also explored the influence mechanism of social capital on the construction of the IOT of new energy vehicle transportation in China-ASEAN. Some suggestions are put forward to stimulate the vitality of social capital and build the IOT of new energy vehicle transportation in China-ASEAN, such as making good top-level design, strengthening guiding funds, putting infrastructure first and making good use of relevant policies.
\end{abstract}

Keywords: China-ASEAN, New energy vehicle, IOT of transportation, Social capital

\section{新能源汽车车联网社会资本投入影响机制分析 \\ 潘翔*, 林兴志}

\author{
广西职业师范学院，南宁市，中国 \\ “通讯作者
}

\section{中文摘要}

近年来中国一东盟新能源汽车蓬勃发展, 但基于新能源汽车的交通物联网还在起步阶段。文章通过分析 中国-东盟新能源汽车交通物联网在大数据、位置服务和共享经济方面的新业态，建立基于社会资本的 中国-东盟新能源汽车交通物联网建设模型, 探索社会资本对中国-东盟新能源汽车交通物联网建设的 影响机理，提出做好顶层设计、强化引导资金、基础设施先行和用好相关政策等激发社会资本活力建 设中国-东盟新能源汽车交通物联网的建议。

关键词: 中国一东盟; 新能源汽车; 交通物联网; 社会资本

\section{1. 引言}

自从2012年我国政府提出新能源汽车发展目标以 来, 相继出台了系列财政补贴、充电桩建设、牌照发放 等政策措施, 驱动了新能源汽车市场的快速发展 ${ }^{[1]}$ 。但 多年来在新能源汽车交通物联网建设上略显不足, 特别 是在中国-东盟领域有所缺失, 发展中社会资本缺乏活 力, 互联互通网络体系建设缓慢, 在不同程度上影响了 我国新能源汽车在东盟市场占有率, 大大落后于欧美日 系列。中国-东盟新能源汽车交通物联网的建设要从技术
研发、基础设施建设、互联互通网络建设和应用系统建 设等方面入手, 分析社会资本对中国-东盟新能源汽车交 通物联网建设的影响机理, 有效激活社会资本, 促进中 国-东盟新能源汽车交通物联网的形成和应用。 


\section{2. 中国-东盟新能源汽车交通物联网新业态}

\section{1. 基于大数据服务的新能源车云网}

新能源汽车交通物联网大数据服务的基本条件是 “厂家一车辆一充电桩一路网一金融”的互联互通, 以及 提供精准的北斗位置服务能力, 形成中国-东盟新能源汽 车统一车云网 ${ }^{[2]}$ 。车云网具备区域性大数据服务与运营 能力, 形成一种从基础设施迈向数据服务的低碳环保新 业态, 以此为基础植入民间资本发展中国-东盟新能源汽 车制造业、交通业、物流业、旅游业、商贸业等的多业 联动。

\section{2. 基于北斗卫星的物联化位置服务}

中国-东盟新能源汽车大数据服务、交通物联网建 设, 离不开基于卫星导航的位置服务, 但在传统燃油汽 车行业, GPS位置服务已经十分成熟, 北斗卫星位置服 务推广举步维艰 ${ }^{[3]}$ 。在新能源汽车领域, 利用北斗卫星 导航系统对东盟国家导航精度、区域地缘优势与数据安 全优势, 与东盟国家共建信息安全放心工程, 通过各种 途径引入多种类型的资本进行投资, 从车辆在途服务、 充电桩位置导航、分时租赁位置管理等方面接入北斗卫 星位置服务, 形成商业化服务模式。

\section{3. 基于共享经济的网格化运营模式}

共享经济下的新能源汽车基础设施共享、分时租赁 和第三方服务, 以其便捷性和低碳性逐渐受到投资者和 创业者的青睐, 当前北京、上海、深圳等城市在推广应 用方面走在东盟各国前列，且大部分为民间资本投入。 东盟各国的新能源汽车发展政策与应用创新模式层出 不穷, 泰国、印尼、马来西来将成为第二大市场, 马来 西亚规划到2020年新能源汽车占国内生产总量的 $85 \%$ 以 上。我国的民间资本应在东盟各国新能源汽车市场上有 所作为, 建设以集约化网络为前提的共享经济交通物联 网, 形成网格化的经济服务新模式。

\section{3. 社会资本对中国-东盟新能源汽车交通物联 网建设影响机理}

\section{1. 基于社会资本的中国-东盟新能源汽车交 通物联网建设模型}

中国-东盟新能源汽车交通物联网的建设有四大关 键环节, 分别是技术研发、基础设施建设、应用系统开
发和平台互联。这四个环节之间，技术研发和基础设施 建设是整个交通物联网的基础, 系统开发和平台互联是 交通物联网的应用和功能体现。在每一个环节，仅靠国 家资本是远远不足以满足建设需求的, 需要社会资本的 投入才能弥补资金的空缺并同时考虑市场的因素。基于 社会资本的中国-东盟新能源汽车交通物联网建设模型 如图1所示。

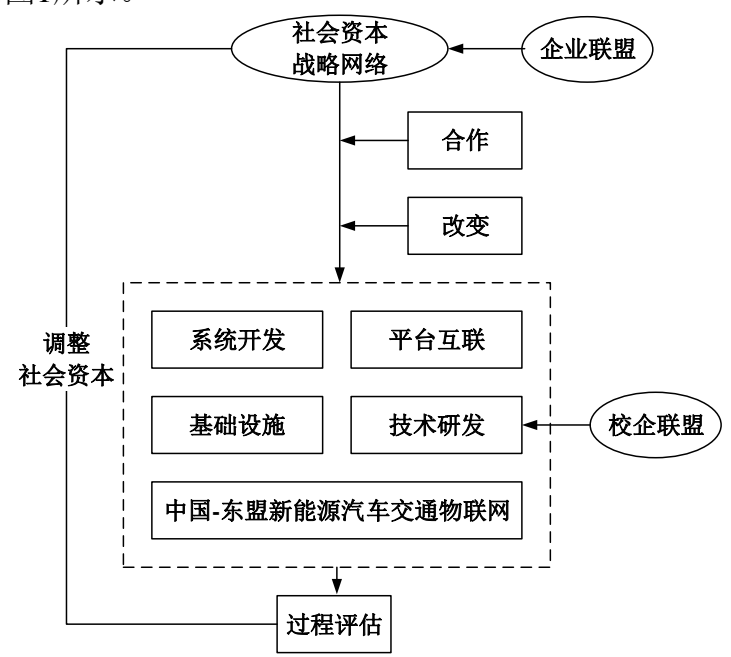

图1 基于社会资本的中国-东盟新能源汽车交通物联 网建设模型

在中国-东盟新能源汽车交通物联网技术研发阶段, 校企联盟是一种典型的互惠互利的社会资本。校企联盟 是由高校和企业通过产学研的方式建立的一个组织结 构, 高校通常负责新能源汽车交通物联网的理论创新, 从新能源汽车的车载终端设计, 到交通物联网软件系统 开发, 都可以承担研发和设计的任务 ${ }^{[4]}$ 。企业的优势在 于能够与市场接轨, 生产出成品并大力推广。双方优势 互补形成的社会网络就是各种社会资本，促进新能源交 通物联网技术的攻关并迅速产业化。

新能源汽车的基础设施建设主要包括充电站的建 设和充电桩的建设。与传统加油站不同的是, 新能源汽 车充电桩可以由个人、企业分别建设。显然, 个人建设 或单个企业建设的充电桩不成体系，即使有对应的交通 物联网充电系统，也无法覆盖整个地区。此时企业联盟 就成为一种适合的社会资本参与到新能源汽车基础建 设中。在这一组织结构里, 企业通过资源整合的方式进 行相互合作，通过统一规划避免企业个体的重复建设， 同时便于实现业务和数据的共享与互通。

系统开发和平台互联阶段, 在统筹基础设施建设的 基础上十分容易实现。否则, 就需要一个建设主体来承 担将不同的新能源交通物联网应用系统进行数据对接、 平台互联的任务。这一建设主体宜由政府相关部门牟 头, 某个企业或企业联盟担任。尤其是涉及中国-东盟多 个地区时, 更需要由不同地区的代表企业共同组成企业 联盟, 便于建设管理。此外, 社会资本战略网络也不是 一成不变的, 在合作实施建设过程中, 有可能会有新的 资本加入，也有可能会有旧的资本退出。而无论是资本 
加入还是退出, 都需要在建设中及时进行过程评估, 并 根据需要调整社会资本的结构或投资额度 ${ }^{[5]}$ 。

\section{2. 社会资本对中国-东盟新能源汽车交通物 联网建设作用机理}

\subsection{1. 社会资本对绿色战略发展的推动作用}

中国-东盟自由贸易区升级版和 “一带一路” 等战略 正步入落实阶段, 我国社会民间资本注入新能源汽车智 能制造阵营, 正在东盟紧密布局, 抢占 “绿色” 新市场。 社会民间资本的东盟投资体系中，灵活性大、机动性强， 发展空间广阔, 从而决定了其在东盟市场中的极核地位 [6]。中国-东盟的新能源汽车产业发展在技术创新与制造 上不缺位, 但在网络互联联通上有所缺失, 这就要求将 零散而有限的资本集中于统一网络建设, 获取集聚化与 关联发展效应，进而辐射带动整体产业发展。

\subsection{2. 社会资本活力对统一平台构建的促进作} 用

我国新能源汽车公共服务领域建立了“车企一省级 一国家级”三级安全监管平台, 但企业与个人车辆、充 电桩站等尚未形成统一的对外服务, 更未向东盟国家延 伸服务。要想建成中国-东盟新能源汽车交通物联网大平 台, 将会面临政策、信息安全等敏感因素, 难度大, 困 难多。社会民间资本未受传统思维束缚, 宜以产业化集 聚为重点, 以车企参与、服务外包共建为载体, 创造条 件建设交通物联网基础设施, 以转产权、跨行业、转身 份、购服务等方式跨区域共建新能源汽车统一车云网服 务平台。

3.2.3 社会资源突破区域发展壁垒的显著优势

社会民间资本灵活多样，调动非国与国政府行为参 与资源能力强。我国新能源汽车走向东盟市场存在政 策、关税壁垒和非关税壁垒限制, 加上欧美日系车辆围 堵, 需要多样化、多模式社会民间资本去投入建设新颖 化、智能化的交通物联网统一云服务平台, 为新能源汽 车走向东西作支撑。通过基础设施的投入, 织牢车企网 络和交通路网; 通过节点型、终端化的北斗卫星位置服 务网络投入, 织密均等化服务网络; 通过沿边金融体系 融合，织牢织密产业化集聚网络。

\section{4. 激发社会资本活力建设中国-东盟新能源汽 车交通物联网建议}

\section{1. 做好顶层设计，打造中国-东盟新能源交 通物联网 “一中心六网络”}

顶层设计是织牢织密中国-东盟新能源交通物联网 建设的关键, 针对新能源车企信息网络互不联通、东盟 各国新能源汽车交通物联网未成规模的形势特点, 做好 中国-东盟新能源交通物联网建设的整体规划，鼓励民间 资本打造 “一中心六网络” : 建设中国-东盟新能源汽车 大数据中心, 连接新能源汽车网、新能源汽车充电桩网、 交通路网、新能源车企网、新能源金融网和北斗卫星服 务网。其中 “六网络” 代表新能源产业的民间资本各大 相关主体, 首先以现有的各车企信息网络为依托, 整合 汽车、充电桩和企业逐步实现互联互通, 同时应用北斗 卫星导航技术为主线与交通路网实现互通，并逐步将汽 车金融服务纳入进来。通过连接销往东盟的车辆与配套 建设的充电桩等基础设施，实现与东盟国家新能源交通 网的对接。大数据中心接收 “六网络” 上传的各种数据 信息, 形成中国-东盟新能源汽车统一车云网数据中心, 并对其进行统计、分析，为政府、车企和车主提供不同 的数据服务。

\section{2. 强化引导资金，构建中国-东盟新能源汽 车民间经济信息网络投资体系}

充分发挥我国中央和地方引导资金作用，出台相关 政策与措施，并进一步融合沿边金融体系，激励社会民 间资本投入中国-东盟新能源汽车交通物联网建设。规 划经济信息网络投资服务体系, 集中发展中国-东盟新 能源汽车交通物联网统一车云网公共服务, 发展新能源 汽车的监管、检测、行业应用服务。开放投资服务领域, 将新能源汽车交通物联网的建设和运营全面向社会资 本开放，培育新能源信息服务市场。以新能源汽车北斗 位置服务、智能充电服务、分时租赁服务为切入点，重 点在干线运输、智能出行、配送、公共交通等领域放开 市场准入，规范市场竞争，吸引更多社会资本介入。开 放投融资领域，创新投融资方式，制定政策鼓励国内社 会资本与东盟各国的政府或企业合作，共同开展当地新 能源交通物联网的建设和运营。

\section{3. 基础设施先行，加强中国-东盟新能源交 通物联网服务网点建设}

鼓励社会资本投资中国-东盟新能源交通物联网基 础设施建设, 包括智能充电站、智能停车场、基础网络 设施、北斗卫星地基增强系统、无线通信基站以及面向 
不同行业的服务网点。当前新能源汽车的基础设施建设 还处于起步阶段, 根据新能源汽车续航能力的技术发 展, 可以采用“城市一乡镇一高速公路”的建设思路, 首 先把城市的智能充电站、停车场配置到位, 满足公共交 通、物流配送和私人出行等方面的需求。北斗卫星地基 增强系统和无线通信基站可以利用现有的设施, 对设施 不足的地区再补充建设。新能源交通物联网服务网点可 以依赖于充电站、停车场或分时租赁网点而存在, 也可 以在适当的场所合理布局, 主要提供交通物联网终端设 备租赁、检测、维修, 以及信息服务和人工服务等。以 此思路将新能源交通物联网基础设施建设延伸到东盟 各国, 结合新能源汽车在东盟的销售网络, 将配套基础 设施布局到车辆行驶的各个地区, 通过统一的标准接入 “一中心六网络”, 逐步形成跨地区的新能源汽车基础设 施服务网。

\section{4. 用好相关政策, 鼓励北斗卫星导航应用与 新能源汽车在中国-东盟协同发展}

以社会资本推进北斗卫星导航应用与新能源汽车 产业协同发展。相对于传统燃油汽车被GPS占领了大部 分市场, 新能源汽车的北斗化更易施行, 可以通过一定 的政策手段进行激励性推广。如对于安装北斗终端的新 能源汽车企业给予适当的补贴或奖励, 对此类车辆出口 东盟的关税进行补贴等, 鼓励社会资本投资东盟新能源 汽车北斗卫星位置服务领域。同时推进北斗卫星服务产 业链与新能源汽车产业链的深度融合, 在技术研发、降 低成本、行业应用等各个方面找到双赢的切入点, 逐步 从政府引导和政策支持转移到发挥市场配置的轨道上 来。

\section{5. 结束语}

新能源汽车由于绿色环保的特性, 得到各国政府的 大力推广, 作为方便新能源汽车使用的交通物联网也在 大力建设之中。对于新能源汽车交通物联网产生的大数 据车云网、北斗位置服务和共享经济等新业态, 社会资 本具有强大的建设和运营优势。在新能源交通物联网的 技术研发、基础设施建设、应用系统开发和平台互联等 方面, 基于社会资本的建设模型反映出社会资本对绿色 战略发展、统一平台构建和突破区域发展壁垒都有促进 作用。为了建好中国-东盟新能源汽车交通物联网, 建议 打造“一中心六网络”,构建民间经济信息网络投资体系， 建设交通物联网服务网点并鼓励北斗卫星导航应用与 新能源汽车在中国-东盟协调发展。

\section{致谢}

本文为国家社会科学基金西部项目（14XJY016） 《中国-东盟自由贸易区交通物联网互联互通服务体系
建设研究》、广西高等学校高水平创新团队及卓越学者 计划（桂教师范(2019)52号-6) 《新能源汽车智能网 联技术研究》的阶段性成果之一。

\section{REFERENCES}

[1] Zhe Meng, The development status of new energy automobile industry and Its Enlightenment to China's development, Commercial Situation. 2017(31).

[2] Yan-Ni DUAN, Jun DONG, Discussion on the development of China's New Energy Vehicle industry, Cars and accessories. 2017(8) 36-37.

[3] Fei WEN, Yong WU, Li-Qun LI, Research on the sustainable development of China's new energy Vehicle industry, Gansu science and technology. 2017, 33(12) 20-22.

[4] Zhu YU. Research on the transformation of new energy vehicle technology achievements from the perspective of social capital, Shanghai automobile. 2013 (2) $1-2,6$.

[5] Ping-Nan RUAN, Shen YU, Hui CHEN, An analysis of the influence mechanism of social capital on the stability of strategic network of enterprises, Enterprise Strategy. 2012, 3(24) 11-14.

[6] Chen-Xi XU, New energy vehicles: although capital is hot and standard is not loose, China's strategic emerging industries. 2016(15) 79-81. 